\title{
Repertoire of SSRs in the Castor Bean Genome and Their Utilization in Genetic Diversity Analysis in Jatropha curcas
}

\author{
Arti Sharma and Rajinder Singh Chauhan \\ Department of Biotechnology \& Bioinformatics, Jaypee University of Information Technology, Waknaghat, P.O. Dumehar Bani, \\ Kandaghat, Solan 173215 , India
}

Correspondence should be addressed to Rajinder Singh Chauhan, rajinder.chauhan@rediffmail.com

Received 9 August 2010; Revised 16 February 2011; Accepted 9 March 2011

Academic Editor: Neil Hall

Copyright (C) 2011 A. Sharma and R. S. Chauhan. This is an open access article distributed under the Creative Commons Attribution License, which permits unrestricted use, distribution, and reproduction in any medium, provided the original work is properly cited.

\begin{abstract}
Castor bean and Jatropha contain seed oil of industrial importance, share taxonomical and biochemical similarities, which can be explored for identifying SSRs in the whole genome sequence of castor bean and utilized in Jatropha curcas. Whole genome analysis of castor bean identified 5,80,986 SSRs with a frequency of 1 per $680 \mathrm{bp}$. Genomic distribution of SSRs revealed that $27 \%$ were present in the non-genic region whereas $73 \%$ were also present in the putative genic regions with $26 \%$ in $5^{\prime}$ UTRs, $25 \%$ in introns, $16 \%$ in $3^{\prime}$ UTRs and $6 \%$ in the exons. Dinucleotide repeats were more frequent in introns, $5^{\prime}$ UTRs and $3^{\prime}$ UTRs whereas trinucleotide repeats were predominant in the exons. The transferability of randomly selected 302 SSRs, from castor bean to $49 \mathrm{~J}$. curcas genotypes and 8 Jatropha species other than J. curcas, showed that 211 ( 70\%) amplified on Jatropha out of which $7.58 \%$ showed polymorphisms in J. curcas genotypes and $12.32 \%$ in Jatropha species. The higher rate of transferability of SSR markers from castor bean to Jatropha coupled with a good level of PIC (polymorphic information content) value ( 0.2 in J. curcas genotypes and 0.6 in Jatropha species) suggested that SSRs would be useful in germplasm analysis, linkage mapping, diversity studies and phylogenetic relationships, and so forth, in J. curcas as well as other Jatropha species.
\end{abstract}

\section{Introduction}

Biofuel is a renewable fuel which can be used as an alternative to or an addition to fossil-derived fuels with multitudes of environmental benefits. Off late, various oil seed plants suited to wide agroclimatic conditions have been explored as sources of future fuels due to the fear that the fossil fuels may get exhausted, in addition to their environmental concerns. Jatropha curcas is a promising bioenergy crop with more than $35 \%$ oil content in its seeds with chemical characteristics of oil suitable to be used in modern combustion engines. The plant species is native to tropical America with a heterozygous genome [1-4]. The taxonomic studies of the genus Jatropha have shown that the J. curcas is a primitive ancestral species due to its morphological distinctness and other Jatropha species evolved from J. curcas with changes in growth habit [5]. J. curcas crosses readily with other Jatropha species forming natural hybrid complexes (J. curcasgossypifolia).
The narrow genetic base in crop plants has been a major limitation in their genetic improvement for desirable traits $[6,7]$. Previous studies based on RAPD, SSR, and AFLP analysis have indicated that the genetic base of $J$. curcas is narrow [8-11]. Basha et al. [11] demonstrated polymorphisms of 61.8 and $35.5 \%$ with RAPDs and ISSRs, respectively. They identified 12 microsatellite primers differentiating the toxic and non-toxic Mexican accessions. Sudheer Pamidimarri et al. [12] identified RAPD, AFLP, and one SSR marker differentiating toxic and non-toxic varieties of J. curcas. The J. curcas lacks basic genome resources such as genetic map, molecular markers, and genome libraries, thereby necessitating the development of additional molecular markers so as to accelerate the process of genetic improvement programmes. The recent sequencing of $J$. curcas genome will enable further progress in its genomics [13].

SSRs occur as frequently as 1 in every $6 \mathrm{~kb}$ in the plant genomes [14]. The functional role of SSRs vary with their location in the genome $[14,15]$. Variations in SSRs in 
5'UTRs and 3'UTRs are known to effect gene expression [16]. For example, SSRs in the $5^{\prime}$ UTRs affect gene regulation and/or gene transcription, and SSRs in the $3^{\prime}$ UTRs may cause transcription slippage $[14,15]$. Large numbers of SSRs have been detected and documented in the transcribed regions of genomes [17, 18] with their usage as genetic markers for genotyping, mapping, and positional cloning of genes in different plant species [19-22].

Conservation in structure and function of genetic loci has been documented and utilized in the development of anchor markers such as in grass genomes [23], crucifers [24], and solanaceous plants [25]. The availability of public genome sequence databases provides an easier alternative for the identification of anchor markers, including SSRs using bioinformatics, thereby reducing cost and time span for their development [26-28]. Wen et al. [29] identified 241 ESTSSRs and genomic SSR markers in cassava and demonstrated their transfer and polymorphisms among J. curcas accessions.

The castor bean (Ricinus communis) is a perennial shrub with $50-55 \%$ seed oil and mainly cultivated in tropical and subtropical areas of India, China, and Brazil. It is taxonomically and biochemically related to J. curcas because both belong to Euphorbiaceae. The high level of synteny can, therefore, be expected between both plant species, which can be exploited to develop anchor markers. Genome sequence of castor bean was surveyed for SSRs and utilized in J. curcas and other Jatropha species [30]. The extent of polymorphisms, in SSRs from putative genic ( $5^{\prime}$ and $3^{\prime}$ UTRs, exons, introns) versus nongenic genome regions and SSRs of different types and repeat motif numbers, was investigated.

\section{Materials and Methods}

2.1. Annotation of Castor Bean Genome for SSRs. The castor bean genome sequence ( $400 \mathrm{Mb})$, consisting of 25,828 contigs (4X coverage), was downloaded from The JCVI website (http://castorbean.tigr.org/), and SSRs were identified using an in-house designed Perl script. The Perl script used regular expressions to locate SSR patterns in the FASTA-formatted sequence files and reported sequence contig ID, SSR motif, number of repeats, and sequence coordinates for each SSR. The minimum repeat unit was defined as six for dinucleotides and five for all other higher-order motifs, including tri-, tetra-, penta-, and hexanucleotides. The FASTA-formatted sequence file was allowed to search for all possible combinations of dinucleotide, trinucleotide, tetranucleotide, and pentanucleotide repeats. Castor bean genome sequence contigs harboring SSRs were annotated for putative open reading frames, including 5'UTRs and 3'UTRs, using gene prediction algorithms of FGenesH (http://linux1.softberry.com/berry.phtml?topic=fgenesh\&group=programs\&subgroup $=$ gfind), because it was cited as the most accurate gene prediction tool $[31,32]$. SSR motifs were identified in exons, introns, 3'UTRs, 5'UTRs, and non-genic regions of castor bean and Primers were designed from the sequences flanking each SSR repeat motif by using Primer 3.0 (http://frodo.wi .mit.edu/primer3/). The target amplicon sizes were set as 300-400 bp with optimal annealing temperature of $60^{\circ} \mathrm{C}$ and the optimal primer length as $20 \mathrm{bp}$. From the total SSRs identified in the castor bean genome, primer pairs were designed for randomly selected 302 SSRs with a repeat motif of $>10$ from different genome regions such as 70 from 5'UTRs, 70 from exons, 42 from $3^{\prime}$ UTRs, 57 from introns, and 63 from the non-genic regions.

2.2. Plant Material, DNA Extraction, and PCR. The J. curcas genotypes were obtained from the National Bureau of Plant Genetic Resources (NBPGR), New Delhi, India (see Table S1 in supplementary material available on line at doi:101155/2011/286089) and Jatropha species, other than J. curcas, from Dr. k.T. Parthiban of Forest College and Research Institute, Tamil Nadu Agriculture University, Mettupalayam, India. A representative set of 49 genotypes of $J$. curcas and 9 species of Jatropha, from different geographical regions of India, was used in diversity analysis. Total genomic DNA was isolated from unfurled leaves according to a modified CTAB-based procedure [33]. The quality of DNA was checked in $1 \%$ agarose gels. The PCR reactions were performed in $25 \mu \mathrm{L}$ reaction volume following thermocycler profiles, that is, $57-55^{\circ} \mathrm{C}$ ( 189 markers $), 52-54^{\circ} \mathrm{C}$ ( 112 markers), and $51^{\circ} \mathrm{C}$ ( 1 marker). Each PCR reaction consisted of $30 \mathrm{ng}$ genomic DNA, varying amounts of primer pairs (0.3$0.4 \mu \mathrm{M}), 1.5 \mathrm{mM} \mathrm{Mg}{ }^{2+}, 200 \mu \mathrm{M}$ dNTPs, and 0.5 units Taq DNA polymerase. Amplification programs included $94^{\circ} \mathrm{C}$ for $5 \mathrm{~min}, 30$ cycles of $94^{\circ} \mathrm{C}$ for $45 \mathrm{sec}$, annealing temperature $\left(57-51^{\circ} \mathrm{C}\right.$ ) for $45 \mathrm{sec}, 72^{\circ} \mathrm{C}$ for $2 \mathrm{~min}$, and a final extension of $7 \mathrm{~min}$ at $72^{\circ} \mathrm{C}$. Ten $\mu \mathrm{L}$ of each PCR product was mixed with $2 \mu \mathrm{L}$ of $10 \mathrm{X}$ gel loading dye $(0.2 \%$ bromophenol blue, $0.2 \%$ xylene cyanol dye, and $30 \%$ glycerol in a TA buffer) and electrophoresed in a $4 \%$ agarose gel prepared in $0.5 \mathrm{X}$ Tris Borate-EDTA (TBE) buffer (0.05 M Tris, $0.05 \mathrm{M}$ boric acid, $1 \mathrm{mM}$, EDTA $\mathrm{pH} 8.0$ ). The gel was run at a constant voltage of 80 volts for 1.5 to $2 \mathrm{~h}$, stained with ethidium bromide, and analyzed using the gel documentation system AlphaImager EP (Alpha Innotech Corp., USA).

2.3. Statistical Analysis. PowerMarker version 3.25 [34] and Gen-AlEx version 6.1 [35] were used to measure variability at each locus: the observed heterozygosity $(\mathrm{HO})$, the expected heterozygosity (HE), the polymorphism information content (PIC), and the deviation from Hardy-Weinberg equilibrium (HW). Deviations from Hardy-Weinberg (HW) and tests for linkage disequilibrium were evaluated using Fisher's exact tests and sequential Bonferroni corrections. The polymorphism information content (PIC) of each microsatellite locus was determined as described by Weir [36]: PIC = $1-\Sigma P_{i}^{2}$, where $P_{i}$ is the frequency of the $i$ th allele in the genotypes examined. Pairwise similarity matrices were generated by Jaccard's coefficient of similarity [37] by using the SIMQUAL format of NTSYS-pc [38]. The presence or absence of amplicons in the genotypes was scored as 1 or 0 , respectively. A dendrogram was constructed by using the unweighted pair group method with arithmetic average (UPGMA) with the SAHN module of NTSYS-pc to show a phenetic representation of genetic relationships as revealed by the similarity coefficient [39]. 


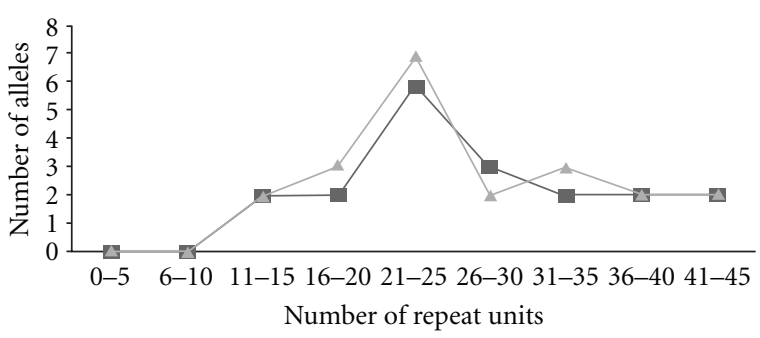

FIgURE 1: Number of alleles per locus for SSRs of different repeat units in J. curcas genotypes (black) and Jatropha species (gray).

\section{Results}

Computational analysis of 25,828 contigs (4X coverage) of castor bean genome identified 5,80,986 SSRs with a frequency of 1 per $680 \mathrm{bp}$. The location of SSRs in the putative genic (exons, introns, UTRs) and non-genic regions of the castor bean genome was inferred by annotation of 25,828 contigs with FGenesH gene prediction algorithm. A total of 31,221 genes were predicted in the 25,828 contigs of castor bean.

3.1. Occurrence and Distribution of SSRs in the Castor Bean Genome. Abundance of SSRs in different regions of the castor bean genome showed that $73 \%$ were located in the putative genic regions and $27 \%$ in the non-genic regions. Comparison of SSR densities in the putative genic regions showed that SSRs were more frequent in 5'UTRs $(26 \%)$ and introns (25\%) followed by $3^{\prime}$ UTRs (16\%) and exons $(6 \%)$. Analysis of SSRs in the castor bean genome showed that 51\% SSRs were dinucleotide repeats, 29\% trinucleotide, $12 \%$ tetranucleotide, and $8 \%$ pentanucleotide repeats. Dinucleotide repeats were more frequent in the non-genic regions (genome), introns, 5'UTRs and 3'UTRs, whereas trinucleotide repeats were more common in the exons. The tetra- and pentanucleotide repeats were randomly distributed. Among dinucleotide repeats, SSRs with (AT) ${ }_{n}$ repeat motif were common $(43 \%)$ with a repeat motif ranging from 7 to 48 . The frequency of repeat motifs differed in different genomic regions for example $(\mathrm{AT})_{n}$ and $(\mathrm{AG})_{n}$ were predominant in $5^{\prime}$ UTRs, $(\mathrm{TA})_{n}$ and $(\mathrm{AATA})_{n}$ in $3^{\prime}$ UTRs, $(\mathrm{AT})_{n}$ and $(\mathrm{TC})_{n}$ in introns, and $(\mathrm{AT})_{n}$ and $(\mathrm{TA})_{n}$ in the non-genic regions. Analysis of trinucleotide repeats frequencies out of total SSRs indicated their predominance in the order of TCT/GAA/CGC/TTC. The trinucleotide repeats are runs of particular amino acids. The most frequent amino acid runs identified in the castor bean SSRs were serine $(\mathrm{TCT})_{n}(16.5 \%)$, glutamate $(\mathrm{GAA})_{n}(13.6 \%)$, arginine $(\mathrm{CGC})_{n}(12.3 \%)$, and phenylalanine $(\mathrm{TTC})_{n}(9.7 \%)$.

3.2. Transferability of SSRs to Jatropha and Their Polymorphism Analysis. The transferability of SSRs (cross genera amplification) from castor bean to Jatropha (J. curcas genotypes and other Jatropha species) for 302 randomly selected SSRs ( 87 from exons, 78 from nongenic regions, 71 from introns and 66 from $5^{\prime}$ and $3^{\prime}$ UTRs) showed that 273 amplified on castor bean out of which 211 amplified in 43 genotypes of
J. curcas. The amplification failure in J. curcas genotypes, Urli-Kanchan, KcJK5, Hissar local, SKN-Big, and Hansraj, was $2.6 \%, 2.6 \%, 4.8 \%, 6.23 \%, 7.1 \%$, and $7.6 \%$, respectively, in comparison to 43 genotypes. Six Jatropha species produced amplicons with 211 primer pairs, except for J. mahotwani, J. multifida, and J. glandulifera, where the percent failure was $4.74 \%, 6.23 \%$, and $8.2 \%$, respectively. Ten percent of the SSRs failed to amplify on castor bean DNA, which was attributed to primer mismatches. Out of 211 SSRs with amplification in Jatropha, 36.01\% were from exons, $21.8 \%$ from introns, $16.6 \%$ from UTRs, and $25.6 \%$ from nongenic regions. Sixteen SSRs from the 5'UTRs (5), nongenic regions (5), introns (3), and exons (3) showed polymorphism in J. curcas genotypes (Table 1). The number of alleles per SSR locus ranged from 2 to 6 with a total of 43 alleles ranging in sizes from $200 \mathrm{bp}$ to $600 \mathrm{bp}$ in J. curcas genotypes (Figure S1). Twenty six SSRs from $5^{\prime} \& 3^{\prime}$ UTRs (12), introns (7), 4 nongenic regions (4), and 3 exons (3) were polymorphic on 9 Jatropha species (J. maheshwarii, J. multifida, J. gossypifolia, J. podagrica, J. glandulifera, J. curcas, J. tanjorensis, J. villosa, and J. integerrima) (Table 2). The number of alleles per SSR locus ranged from 2 to 7 in Jatropha species (Figure S2). Five SSRs (JM8, JM10, JM11, JM15, and JM16) showed polymorphisms in J. curcas genotypes as well as Jatropha species. The transferability of SSRs was the highest to J. curcas $(\sim 70 \%)$ and the lowest to J. glandulifera (58\%) with a transferability of $63-68 \%$ to other species. The level of polymorphism was higher $(37.8 \%)$ in SSRs from 5 'UTRs followed by $24.3 \%$ from introns, $18.9 \%$ from non-genic regions, $10.8 \%$ from exons, and $8.10 \%$ from $3^{\prime}$ UTRs. The SSRs with dinucleotide repeat motifs showed higher levels of polymorphisms compared to trinucleotide repeats. Out of 37 SSRs, which were polymorphic in J. curcas and other Jatropha species, 35 (94.5\%) were dinucleotide repeats. Tetra- and pentanucleotide repeats did not show any polymorphism in J. curcas and other Jatropha species.

Out of all SSRs, which were successfully transferred to $J$. curcas and other Jatropha species, 50\% contained 15 to 30 repeat units whereas $20 \%$ of the SSRs had repeat units of $>30$. The majority of SSRs with successful amplification and polymorphisms contained more than 15 repeat units (Table 3). The PIC values for polymorphic SSRs in J. curcas genotypes and Jatropha species varied from 0.1 to 0.5 with an average of 0.2 and 0.3 to 0.7 with an average of 0.5 , respectively. The SSRs with dinucleotide repeat motifs showed higher allele numbers (average 2.7 per locus) followed by trinucleotide (average alleles 2.3 per locus). To understand possible relationship between polymorphism of SSR markers with repeat unit length in J. curcas genotypes and Jatropha species, a line graph was plotted between repeat unit length and numbers of alleles detected (Figure 1). Wide variation in the number of alleles for SSRs with 16 and 25 repeat motifs was seen compared to SSRs with low or high numbers of repeat motifs. An exception to this observation was for SSR, JM15, which contained maximum number of repeat units (TA) 42 with only two alleles, whereas SSR, JM20 with lower repeat motifs $(\mathrm{TA})_{23}$ showed the highest number of alleles (7). 
TABLE 1: SSRs used to detect polymorphisms in Jatropha curcas genotypes.

\begin{tabular}{|c|c|c|c|c|c|c|c|}
\hline SSR locus & $\begin{array}{l}\text { Repeat } \\
\text { motif }\end{array}$ & Primer sequence & $\begin{array}{l}\text { Location of } \\
\text { repeat motif }\end{array}$ & $\begin{array}{c}\text { No. of } \\
\text { alleles } \\
\text { detected }\end{array}$ & $\mathrm{HO}$ & $\mathrm{HE}$ & PIC \\
\hline JM1 & $(\mathrm{TA})_{22}$ & $\begin{array}{l}\text { F: TTTGAGTGCTCCTATTTGGCTAGAA } \\
\text { R: CCAAATGACAAGTAGGCAGAACTTT }\end{array}$ & $5^{\prime} \mathrm{UTR}$ & 3 & 0.1832 & 0.1833 & 0.2 \\
\hline JM2 & $(\mathrm{TA})_{20}$ & $\begin{array}{l}\text { F: GAAATGAGAAGCCTTTACCCTCATT } \\
\text { R: AGAGGGAGAAGGGAGAAAGCAGT }\end{array}$ & $5^{\prime} \mathrm{UTR}$ & 2 & 0.5114 & 0.5115 & 0.4 \\
\hline JM3 & $(\mathrm{AT})_{20}$ & $\begin{array}{l}\text { F: TCATCGAATGGTAGAGAACTAATGG } \\
\text { R: TTAATTCGGATTCTGAGTCTTGAGG }\end{array}$ & $5^{\prime} \mathrm{UTR}$ & 2 & 0.2832 & 0.2832 & 0.3 \\
\hline JM4 & $(\mathrm{AT})_{29}$ & $\begin{array}{l}\text { F: ATTTGATACAGGAGCAGACCTCAAC } \\
\text { R: GTGGTGGTTATGGTGGTAAATTTGT }\end{array}$ & $5^{\prime} \mathrm{UTR}$ & 2 & 0.1166 & 0.1166 & 0.1 \\
\hline JM5 & $(\mathrm{TTA})_{22}$ & $\begin{array}{l}\text { F: GCAGAAACTCGGTAGAACTGTGAGT } \\
\text { R:GGCATAATCTACTGTTATCTCATCCC }\end{array}$ & $5^{\prime} \mathrm{UTR}$ & 3 & 0.2998 & 0.2999 & 0.2 \\
\hline JM6 & $(\mathrm{AT})_{24}$ & $\begin{array}{l}\text { F: CCAATCGGAGAGTGAAATAGAACAT } \\
\text { R: TCTCGAGTTTAAATCTTGGGTATGC }\end{array}$ & Intron & 6 & 0.2149 & 0.2149 & 0.2 \\
\hline JM7 & $(\mathrm{TA})_{24}$ & $\begin{array}{l}\text { F: TGAGAGTGTTACAGAGAGTGTTGCTT } \\
\text { R: TGTTACTGCTGAAACATGGAATGAC }\end{array}$ & Intron & 4 & 0.1499 & 0.1499 & 0.1 \\
\hline JM8 & $(\mathrm{TC})_{23}$ & $\begin{array}{l}\text { F: GAATTTAGAAGCCACATTTGAGACG } \\
\text { R: CCTATGTAACCCAAGAAAGACGATG }\end{array}$ & Intron & 3 & 0.1499 & 0.1499 & 0.1 \\
\hline JM9 & $(\mathrm{TC})_{15}$ & $\begin{array}{l}\text { F: GTTAGAGAAGGCCAAATTGAAACTG } \\
\text { R: ACTTCATTACGTCGAGAGATATCGG }\end{array}$ & Exon & 2 & 0.1832 & 0.1833 & 0.2 \\
\hline JM10 & $(\mathrm{GAA})_{15}$ & $\begin{array}{l}\text { F: TGGAAGACGAATACTATGACGATGA } \\
\text { R: CAGGTGCTACTTCTTCTTCTTCAGG }\end{array}$ & Exon & 2 & 0.1149 & 0.115 & 0.1 \\
\hline JM11 & $(\mathrm{CAT})_{12}$ & $\begin{array}{l}\text { F: GCATGCAAACCCTGAATTATGTACT } \\
\text { R: GCTGCTGACTCTGTTTCTCCTTCTA }\end{array}$ & Exon & 2 & 0.2149 & 0.2149 & 0.2 \\
\hline JM12 & $(\mathrm{TA})_{33}$ & $\begin{array}{l}\text { F: TTGGCTCATAATAACTCCTCAAAGC } \\
\text { R: GCGAGTGCTGTCTAAAGCCTAATTT }\end{array}$ & Non genic & 2 & 0.1149 & 0.115 & 0.1 \\
\hline JM13 & $(\mathrm{AT})_{25}$ & $\begin{array}{l}\text { F: GTCAGTACCTACAAGCTGCCTTCAT } \\
\text { R: GCCTTTGGATGAACCTATTCACATA }\end{array}$ & Non genic & 5 & 0.1832 & 0.1833 & 0.2 \\
\hline JM14 & $(\mathrm{AT})_{34}$ & $\begin{array}{l}\text { F: GTTTGGCGATGAGCTAATTGAGATT } \\
\text { R: GGCTCGAACCTTTCTGATCTAATGT }\end{array}$ & Non genic & 2 & 0.2732 & 0.2732 & 0.2 \\
\hline JM15 & $(\mathrm{TA})_{42}$ & $\begin{array}{l}\text { F: TGTAGATAGCCTTAGCTGTGCATTG } \\
\text { R: GTACTCTCGAGGGAGTTGATTGTGT }\end{array}$ & Non genic & 2 & 0.5397 & 0.5398 & 0.5 \\
\hline JM16 & $(\mathrm{TA})_{38}$ & $\begin{array}{l}\text { F: TTGGCTCATAATAACTCCTCAAAGC } \\
\text { R: GCGAGTGCTGTCTAAAGCCTAATTT }\end{array}$ & Non genic & 2 & 0.4481 & 0.4481 & 0.4 \\
\hline
\end{tabular}

JM: Jatropha microsatellite; F: forward; R: reverse.

3.3. Genetic Diversity Analysis among J. curcas Genotypes and Jatropha Species. The major allele frequency (MAF) ranged from 0.4 to 0.9 for $J$. curcas genotypes and 0.1 to 0.5 for Jatropha species. The observed heterozygosity (HO) ranged from 0.1 to 0.5 (mean $=0.2$ ) in $J$. curcas genotypes and 0.4 to 0.7 (mean $=0.6$ ) in Jatropha species, and expected ( $\mathrm{HE})$ heterozygosities ranged from 0.1 to 0.5 ( mean $=0.2$ ) in J. curcas genotypes and 0.4 to 0.7 (mean $=0.6$ ) in Jatropha species. Hardy-Weinberg probability tests revealed no significant deviations from expected genotype proportions $(P>.004)$. There was no evidence of linkage disequilibrium among loci $(P>.001)$ after corrections for multiple tests.

Phylogenetic relationships among different genotypes of J. curcas and 9 species of Jatropha were inferred based on SSRs analysis. Jaccard's genetic coefficient for J. curcas genotypes varied from 1.08 to 9.02 . The highest genetic dissimilarity co-efficient (9.02) was observed between 16 polymorphic SSRs in J. curcas genotypes while the lowest value (1.08) was measured between eight combinations. The UPGMA cluster analysis of the Jaccard's co-efficient generated a dendrogram for J. curcas genotypes, which illustrated the overall genetic relationship among genotypes (Figure 2). Cluster analysis indicated six distinct clusters comprising J. curcas genotypes. The J. curcas genotype 1 (Urli-Kanchan) and 32 (Hissar local) remained as outliers and formed the first and sixth clusters, respectively.

\section{Discussion}

Genomic resources of castor bean have been successfully used for the development and utilization of SSR markers in J. curcas and other Jatropha species, thereby establishing that the SSR markers are a valuable genetic resource for investigating relationships and comparative mapping in Euphorbiaceae. The availability of whole genome sequences and comparative genomics have opened up several avenues for the identification of anchor makers through computational approaches, thus avoiding tedious, costly, and time consuming techniques 
TABLE 2: SSRs used to detect polymorphisms in Jatropha species.

\begin{tabular}{|c|c|c|c|c|c|c|c|}
\hline SSR locus & $\begin{array}{c}\text { Repeat } \\
\text { motif }\end{array}$ & Primer sequence & $\begin{array}{l}\text { Location of } \\
\text { repeat motif }\end{array}$ & $\begin{array}{c}\text { No. of } \\
\text { alleles } \\
\text { detected }\end{array}$ & $\mathrm{HO}$ & $\mathrm{HE}$ & PIC \\
\hline JM8 & $(\mathrm{TC})_{23}$ & $\begin{array}{l}\text { F: GAATTTAGAAGCCACATTTGAGACG } \\
\text { R: CCTATGTAACCCAAGAAAGACGATG }\end{array}$ & Intron & 3 & 0.7654 & 0.7654 & 0.7 \\
\hline JM10 & $(\mathrm{GAA})_{15}$ & $\begin{array}{l}\text { F: TGGAAGACGAATACTATGACGATGA } \\
\text { R: CAGGTGCTACTTCTTCTTCTTCAGG }\end{array}$ & Exon & 2 & 0.5925 & 0.5926 & 0.5 \\
\hline JM11 & $(\mathrm{CAT})_{12}$ & $\begin{array}{l}\text { F: GCATGCAAACCCTGAATTATGTACT } \\
\text { R: GCTGCTGACTCTGTTTCTCCTTCTA }\end{array}$ & Exon & 2 & 0.5679 & 0.5679 & 0.5 \\
\hline JM15 & $(\mathrm{TA})_{42}$ & $\begin{array}{l}\text { F: TGTAGATAGCCTTAGCTGTGCATTG } \\
\text { R: GTACTCTCGAGGGAGTTGATTGTGT }\end{array}$ & Non genic & 2 & 0.4938 & 0.4938 & 0.4 \\
\hline JM16 & $(\mathrm{TA})_{38}$ & $\begin{array}{l}\text { F: TTGGCTCATAATAACTCCTCAAAGC } \\
\text { R: GCGAGTGCTGTCTAAAGCCTAATTT }\end{array}$ & Non genic & 2 & 0.6913 & 0.6914 & 0.6 \\
\hline JM17 & $(\mathrm{TA})_{31}$ & $\begin{array}{l}\text { F: CTTCTCAGCAACATCACATCAAACT } \\
\text { R: CGCTAAGTTACATAGGACAAAGGGA }\end{array}$ & 5'UTR & 3 & 0.6172 & 0.6173 & 0.6 \\
\hline JM18 & $(\mathrm{AT})_{25}$ & $\begin{array}{l}\text { F: ATTCAGGCCATCCACATAGTCTAAC } \\
\text { R: GACCCTATTGATTGATTTAAGAGCC }\end{array}$ & $5^{\prime} \mathrm{UTR}$ & 2 & 0.5925 & 0.5926 & 0.5 \\
\hline JM19 & $(\mathrm{TA})_{33}$ & $\begin{array}{l}\text { F: GCCTTAGTTGTGCATTGCTCTATTT } \\
\text { R: ACTCAAACTTATGTCCCAATCGTCT }\end{array}$ & $5^{\prime}$ UTR & 2 & 0.7407 & 0.7407 & 0.7 \\
\hline JM20 & $(\mathrm{TA})_{23}$ & $\begin{array}{l}\text { F: AGATTTAGAAATGGTAATAGGGCGG } \\
\text { R: GACCTATCCGTGTCGTGTAGATTT }\end{array}$ & $5^{\prime}$ UTR & 7 & 0.6419 & 0.642 & 0.6 \\
\hline JM21 & $(\mathrm{AT})_{25}$ & $\begin{array}{l}\text { F: GCAAGAAATAAGGTACAACCGAAAC } \\
\text { R: GTGAGCAATTACCAAAGGAAACAAG }\end{array}$ & $5^{\prime}$ UTR & 2 & 0.6913 & 0.6914 & 0.6 \\
\hline JM22 & $(\mathrm{AT})_{29}$ & $\begin{array}{l}\text { F: ATGCTATCGGAATAGATCCTTCGAG } \\
\text { R: TGGTAAACAAGAGTTGAGGGTTAGG }\end{array}$ & $5^{\prime} \mathrm{UTR}$ & 3 & 0.4444 & 0.4444 & 0.3 \\
\hline JM23 & $(\mathrm{AT})_{32}$ & $\begin{array}{l}\text { F: GAGATGGAAATGATTGGTGTTGAGT } \\
\text { R: CGCCTCATCCTCACATTATACACTT }\end{array}$ & $5^{\prime} \mathrm{UTR}$ & 3 & 0.7654 & 0.7654 & 0.7 \\
\hline JM24 & $(\mathrm{AT})_{20}$ & $\begin{array}{l}\text { F: TGATGGATTGAGAACTGAAGAGGAT } \\
\text { R: ACTCTAATTAGGCCCAGATTCCAAC }\end{array}$ & $5^{\prime} \mathrm{UTR}$ & 4 & 0.6913 & 0.6914 & 0.6 \\
\hline JM25 & $(\mathrm{CT})_{20}$ & $\begin{array}{l}\text { F: CTGACATATCTTATTGGGTGTGGAA } \\
\text { R: TGTAAGAGTATCATCCATTTGCCAG }\end{array}$ & $5^{\prime} \mathrm{UTR}$ & 2 & 0.6913 & 0.6914 & 0.6 \\
\hline JM26 & $(\mathrm{TC})_{18}$ & $\begin{array}{l}\text { F: GCCTTTAAGAGATTGATGGCAACTA } \\
\text { R: AAGTATTCATATGCCCTAAGCCTCC }\end{array}$ & $3^{\prime}$ UTR & 2 & 0.7160 & 0.716 & 0.7 \\
\hline JM27 & $(\mathrm{TA})_{24}$ & $\begin{array}{l}\text { F: TTGGAGGTTACAATCAATGGCA } \\
\text { R: GCATGTGCCCGAATTGAATA }\end{array}$ & $3^{\prime}$ UTR & 3 & 0.7654 & 0.7654 & 0.7 \\
\hline JM28 & $(\mathrm{AT})_{27}$ & $\begin{array}{l}\text { F: CCATTTGGTGTTAATCACATGAGTC } \\
\text { R: GACAATAGTGATGTTGGATTCCACT }\end{array}$ & $3^{\prime}$ UTR & 2 & 0.7160 & 0.716 & 0.7 \\
\hline JM29 & $(\mathrm{AT})_{25}$ & $\begin{array}{l}\text { F: CTGTTTGAGGATCAGACTTTGAAGC } \\
\text { R:AAAGAAATAATGAGGAGGGAGGTTG }\end{array}$ & Intron & 2 & 0.7160 & 0.716 & 0.7 \\
\hline JM30 & $(\mathrm{AT})_{25}$ & $\begin{array}{l}\text { F: GCATGGAAATTCAATTCTGTGCTAC } \\
\text { R: TTTGGTGATGAGGATTGTTGCT }\end{array}$ & Intron & 2 & 0.7160 & 0.716 & 0.7 \\
\hline JM31 & $(\mathrm{ATA})_{19}$ & $\begin{array}{l}\text { F: TGCTCCCAGTAAGCATAAGAAGAAG } \\
\text { R: CTTGCTCGGTTACCATTACCATTAC }\end{array}$ & Intron & 2 & 0.7160 & 0.716 & 0.7 \\
\hline JM32 & $(\mathrm{AT})_{22}$ & $\begin{array}{l}\text { F: AGCAAGAAACCATACTTCGAGTGTC } \\
\text { R: GAGATGCCAACCTTTGTGATTAGTT }\end{array}$ & Intron & 2 & 0.6666 & 0.6667 & 0.6 \\
\hline JM33 & $(\mathrm{GA})_{21}$ & $\begin{array}{l}\text { F: TTCAATAACAGATTTGGCTAGGCTC } \\
\text { R: GACAATTGAAAGGTGCAATCCTAGT }\end{array}$ & Intron & 3 & 0.4938 & 0.4938 & 0.4 \\
\hline JM34 & $(\mathrm{AT})_{24}$ & $\begin{array}{l}\text { F: CAGACCCATCTGATCATCATTGTAG } \\
\text { R: TCCTCAGGTAAATTGCTCATCTTTC }\end{array}$ & Intron & 3 & 0.5679 & 0.5679 & 0.5 \\
\hline JM35 & $(\mathrm{CT})_{12}$ & $\begin{array}{l}\text { F: CAGCGTCCCTCTCTCTCTTCC } \\
\text { R: AGGAAGTTGAGGGACCAAATTGTA }\end{array}$ & Exon & 2 & 0.6419 & 0.642 & 0.6 \\
\hline JM36 & $(\mathrm{AT})_{29}$ & $\begin{array}{l}\text { F: GAAAGCTAGAAATCAATGAACGCAC } \\
\text { R: TCATTTAGTACATTGACCGGAGACA }\end{array}$ & Non genic & 3 & 0.6419 & 0.642 & 0.6 \\
\hline JM37 & $(\mathrm{AAT})_{16}$ & $\begin{array}{l}\text { F: AATCACATCAGTTGTAACGGCA } \\
\text { R: ATAATCTGATGGTTCAGTCAGCTCC }\end{array}$ & Non genic & 3 & 0.7407 & 0.7407 & 0.7 \\
\hline
\end{tabular}




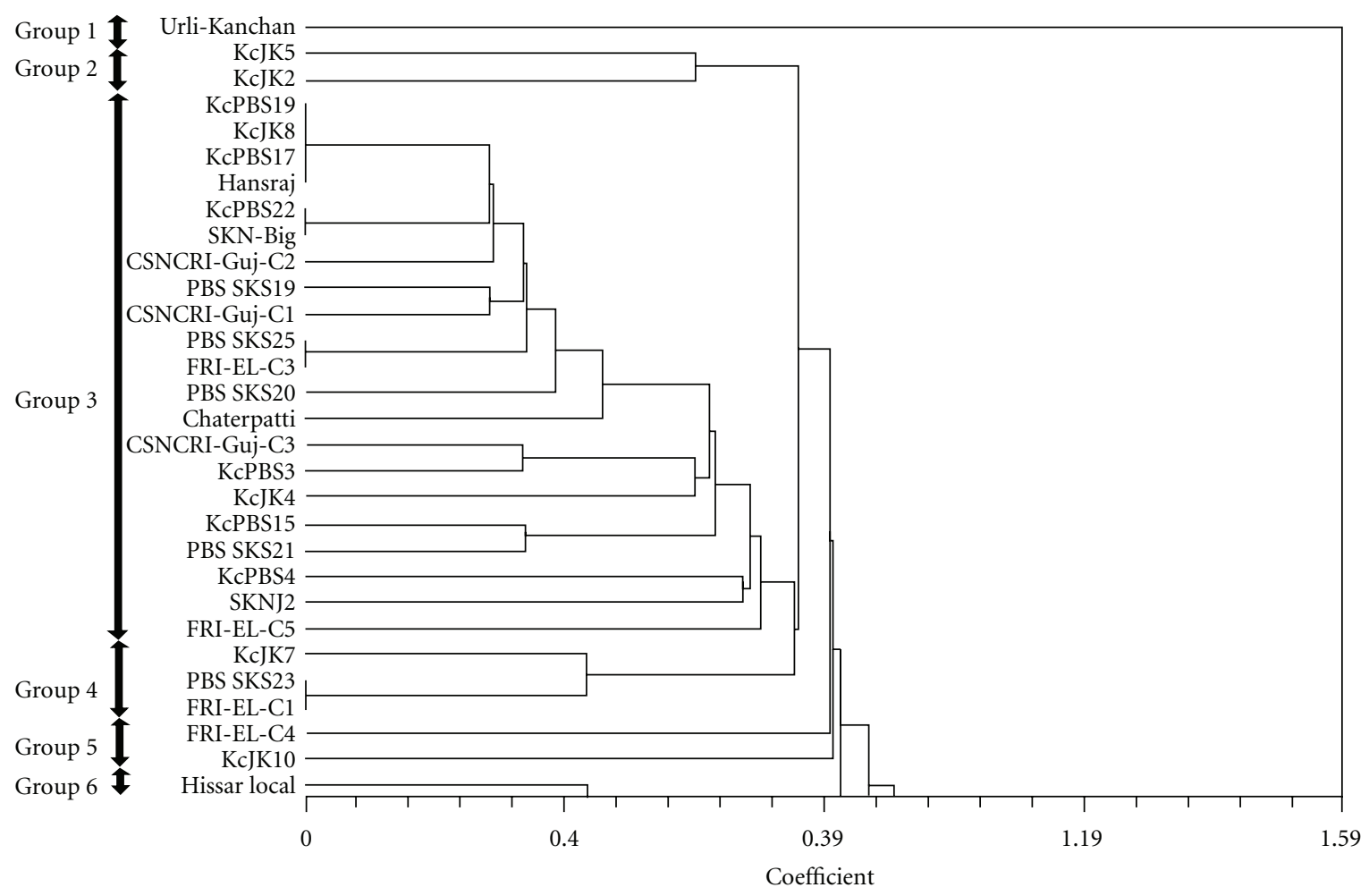

FiguRE 2: Dendrogram based on allele sharing genetic distances of 49 genotypes of J. curcas on the basis of Jaccard's similarity coefficient.

TABLE 3: Extent of amplification and polymorphism among SSRs of varying repeat units in J. curcas.

\begin{tabular}{lccc}
\hline Repeat units & SSRs tested $(\%)$ & SSRs with amplification $(\%)^{1}$ & Polymorphic SSRs $(\%)^{2}$ \\
\hline $10-15$ & 11 & 3.00 & 1.89 \\
$16-20$ & 13 & 12.26 & 3.31 \\
$21-25$ & 14 & 18.20 & 6.16 \\
$26-30$ & 26 & 20.20 & 3.31 \\
$31-35$ & 22 & 9.00 & 1.89 \\
$36-40$ & 8 & 3.20 & 0.47 \\
$>40$ & 6 & 4.00 & 0.47 \\
\hline
\end{tabular}

${ }^{1}$ Percent amplification was calculated as: SSRs amplified from the corresponding repeat unit X100/total no. of SSRs tested for amplification from the corresponding repeat unit.

${ }^{2}$ Percent polymorphism was calculated as: SSRs polymorphic from the corresponding repeat unit X100/total no. of SSRs amplified from the corresponding repeat unit.

of genomic or EST library construction for the identification of SSRs. High transferability (70\%) of castor bean SSRs to J. curcas and other Jatropha species shows higher levels of sequence identity between both plant species. The transferability of EST-SSRs (44.63\%) and genomic SSRs (29.67\%) has been achieved from cassava to J. curcas [29]. The high levels of structural and functional synteny has also been observed for other loci between castor bean and $J$. curcas such as for genes involved in the biosynthesis of fatty acids biosynthesis (Sharma \& Chauhan, unpublished). The distribution of SSRs in different putative genic regions of the castor bean revealed that SSRs were more prevalent in the $5^{\prime}$ UTRs, which was analogous to genomic distributions of SSRs in A. thaliana, B. rapa and O. sativa $[18,40-45]$. Contrary to the genomes of $A$. thaliana and $O$. sativa where
$(\mathrm{AG})_{n},(\mathrm{AT})_{n}$ and $(\mathrm{AC})_{n}$ repeats were more abundant, the castor bean genome contained more $(\mathrm{AT})_{n}$ dinucleotide repeats, which was analogous to $B$. rapa genome $[41,44,45]$. Trinucleotide SSRs were more frequent in the exonic regions of castor bean genome analogous to other genomes. Majority of trinucleotide repeats were in the coding regions of the castor bean genome, which may encode amino acid runs. Frequent occurrence of trinucleotide SSRs in the coding regions has been attributed to their advantages in codon usage whereas the suppression of non-trinucleotide SSRs in the coding regions may be due to the possible risks of their involvement in frameshift mutations [15, 44, 46]. Although biased distribution of codon repeats has been demonstrated in several eukaryotic genomes [15, 41, 44, 46, 47], yet the over-representation of specific amino acid runs varies. 
The most frequent amino acid runs in A. thaliana are serine, proline, glycine, glutamate, glutamine, and aspartate, and those in $O$. sativa are alanine, glycine, proline, serine, arginine, and glutamate [41]. The most frequent amino acid runs in Brassica rapa are serine, glutamic acid, aspartic acid, glycine, lysine, and asparagines [45]. Wheras the most frequent amino acid runs in the castor bean SSRs were serine, glutamate, arginine and phenylalanine, which are also the most frequent amino acid runs in the SSRs of other plant genomes $[46,48,49]$.

It has been reported that SSRs with longer repeat motifs are more informative for detection of polymorphisms [43, 50-54]. For example, Sharma and Chauhan [55] identified an SSR with a long repeat motif (TTC) $)_{31}$ in the iron transporter genes of maize showing high polymorphisms among maize inbreds compared to other repeat motifs. On the contrary, we found that the repeat motifs of 16-30 repeat length showed higher polymorphisms than longer repeat motifs of $>30$ repeat units. Other studies have also found no relationship or weak correlation between SSR polymorphisms and repeat unit length [56-58]. High polymorphisms have been detected in SSRs with dinucleotide repeat motifs in Pearl millet [59] and White clover [60].

Overall low level of genetic diversity was detected among J. curcas genotypes compared to Jatropha species. Basha and Sujatha [9] have reported low levels of diversity among Indian accessions of $J$. curcas indicating a narrow genetic base. Ganesh Ram et al. [1] have shown that polymorphisms with 26 RAPD primers were considerably higher $(80.2 \%)$ in 8 Jatropha species compared to J. curcas genotypes. Sun et al. [10] reported one SSR with two alleles and $14.3 \%$ polymorphism with 7 AFLP primers in J. curcas.

The study concludes that the dinucleotide repeat motifs in SSRs, from 5'UTR regions with repeat unit length of 1630 , showed higher polymorphisms suggesting that additional primers can be designed from those SSRs with a higher probability of detecting polymorphisms on castor bean and J. curcas and other Jatropha species (Table S2). The SSR markers developed in this study would be very useful for germplasm analysis, population genetic structure and taxonomic relationships in J. curcas and related taxa.

\section{Acknowledgment}

The authors are thankful to the Department of Biotechnology, Ministry of Science and Technology, Government of India for providing research grant to R. S. Chauhan.

\section{References}

[1] S. Ganesh Ram, K. T. Parthiban, R. Senthil Kumar, V. Thiruvengadam, and M. Paramathma, "Genetic diversity among Jatropha species as revealed by RAPD markers," Genetic Resources and Crop Evolution, vol. 55, no. 6, pp. 803-809, 2008.

[2] H. S. Ginwal, S. S. Phartyal, P. S. Rawat, and R. L. Srivastava, "Seed source variation in morphology, germination and seedling growth of Jatropha curcas Linn. in Central India," Silvae Genetica, vol. 54, no. 2, pp. 76-80, 2005.
[3] A. J. Prabakaran and M. Sujatha, "Jatropha tanjorensis Ellis and Saroja, a natural interspecific hybrid occurring in Tamil Nadu, India," Genetic Resources and Crop Evolution, vol. 46, no. 3, pp. 213-218, 1999.

[4] B. Dehgan, "Phylogenetic significance of interspecific hybridization in Jatropha (Euphorbiaceae)," Systematic Botany, vol. 9, pp. 467-478, 1984.

[5] B. Dehgan and G. L. Webster, "Morphology and infrageneric relationships of the genus Jatropha (Euphorbiaceae)," University of California Publications in Botany, vol. 74, pp. 1-73, 1979.

[6] S. D. Basha and M. Sujatha, "Genetic analysis of Jatropha species and interspecific hybrids of Jatropha curcas using nuclear and organelle specific markers," Euphytica, vol. 168, no. 2, pp. 197-214, 2009.

[7] J. A. Callow, B. V. Ford-Lloyd, and H. J. Newbury, "Biotechnology and plant genetic resources: conservation and use," Euphytica, vol. 101, pp. 49-76, 1998.

[8] J. L. Bennetzen, P. Sanmiguel, M. Chen, A. Tikhonov, M. Francki, and Z. Avramova, "Grass genomes," Proceedings of the National Academy of Sciences of the United States of America, vol. 95, no. 5, pp. 1975-1978, 1998.

[9] S. D. Basha and M. Sujatha, "Inter and intra-population variability of Jatropha curcas (L.) characterized by RAPD and ISSR markers and development of population-specific SCAR markers," Euphytica, vol. 156, pp. 375-386, 2007.

[10] Q.-B. Sun, L.-F. Li, Y. Li, G.-J. Wu, and X.-J. Ge, "SSR and AFLP markers reveal low genetic diversity in the biofuel plant Jatropha curcas in China," Crop Science, vol. 48, no. 5, pp. 1865-1871, 2008.

[11] S. D. Basha, G. Francis, H. P.S. Makkar, K. Becker, and M. Sujatha, "A comparative study of biochemical traits and molecular markers for assessment of genetic relationships between Jatropha curcas L. germplasm from different countries," Plant Science, vol. 176, no. 6, pp. 812-823, 2009.

[12] D. V. N. Sudheer Pamidimarri, S. Singh, S. G. Mastan, J. Patel, and M. P. Reddy, "Molecular characterization and identification of markers for toxic and non-toxic varieties of Jatropha curcas L. using RAPD, AFLP and SSR markers," Molecular Biology Reports, vol. 36, no. 6, pp. 1357-1364, 2009.

[13] S. Sato, H. Hirakawa, S. Isobe et al., "Sequence analysis of the genome of an oil-bearing tree, Jatropha curcas L," DNA Research, vol. 18, no. 1, pp. 65-76, 2011.

[14] P. K. Gupta and R. K. Varshney, "The development and use of microsatellite markers for genetic analysis and plant breeding with emphasis on bread wheat," Euphytica, vol. 113, no. 3, pp. 163-185, 2000.

[15] Y. C. Li, A. B. Korol, T. Fahima, and E. Nevo, "Microsatellites within genes: structure, function, and evolution," Molecular Biology and Evolution, vol. 21, no. 6, pp. 991-1007, 2004.

[16] V. Decroocq, M. G. Favé, L. Hagen, L. Bordenave, and S. Decroocq, "Development and transferability of apricot and grape EST microsatellite markers across taxa," Theoretical and Applied Genetics, vol. 106, no. 5, pp. 912-922, 2003.

[17] U. Lagercrantz, H. Ellegren, and L. Andersson, "The abundance of various polymorphic microsatellite motifs differs between plants and vertebrates," Nucleic Acids Research, vol. 21, no. 5, pp. 1111-1115, 1993.

[18] M. Morgante, M. Hanafey, and W. Powell, "Microsatellites are preferentially associated with nonrepetitive DNA in plant genomes," Nature Genetics, vol. 30, no. 2, pp. 194-200, 2002.

[19] C. Schlotterer, "Evolutionary dynamics of microsatellite DNA," Chromosoma, vol. 109, no. 6, pp. 365-371, 2000.

[20] C. M. Marques, R. P. V. Brondani, D. Grattapaglia, and R. Sederoff, "Conservation and synteny of SSR loci and QTLs for 
vegetative propagation in four Eucalyptus species," Theoretical and Applied Genetics, vol. 105, no. 2-3, pp. 474-478, 2002.

[21] T. Thiel, W. Michalek, R. K. Varshney, and A. Graner, "Exploiting EST databases for the development and characterization of gene-derived SSR-markers in barley (Hordeum vulgare L.)," Theoretical and Applied Genetics, vol. 106, no. 3, pp. 411-422, 2003.

[22] S. P. Kumpatla and S. Mukhopadhyay, "Mining and survey of simple sequence repeats in expressed sequence tags of dicotyledonous species," Genome, vol. 48, no. 6, pp. 985-998, 2005.

[23] J. L. Bennetzen and W. Ramakrishna, "Numerous small rearrangements of gene content, order and orientation differentiate grass genomes," Plant Molecular Biology, vol. 48, no. 5-6, pp. 821-827, 2002.

[24] T. Axelsson, O. Shavorskaya, and U. Lagercrantz, "Multiple flowering time QTLs within several Brassica species could be the result of duplicated copies of one ancestral gene," Genome, vol. 44, no. 5, pp. 856-864, 2001.

[25] C. S. Barry, R. P. McQuinn, MI. Y. Chung, A. Besuden, and J. J. Giovannoni, "Amino acid substitutions in homologs of the Stay-Green protein are responsible for the green-flesh and chlorophyll retainer mutations of tomato and pepper," Plant Physiology, vol. 147, no. 1, pp. 179-187, 2008.

[26] R. V. Kantety, M. La Rota, D. E. Matthews, and M. E. Sorrells, "Data mining for simple sequence repeats in expressed sequence tags from barley, maize, rice, sorghum and wheat," Plant Molecular Biology, vol. 48, no. 5-6, pp. 501-510, 2002.

[27] A. J. Robinson, C. G. Love, J. Batley, G. Barker, and D. Edwards, "Simple sequence repeat marker loci discovery using SSR primer," Bioinformatics, vol. 20, no. 9, pp. 1475-1476, 2004.

[28] R. K. Varshney, A. Graner, and M. E. Sorrells, "Genic microsatellite markers in plants: features and applications," Trends in Biotechnology, vol. 23, no. 1, pp. 48-55, 2005.

[29] M. Wen, H. Wang, Z. Xia, M. Zou, C. Lu, and W. Wang, "Developmenrt of EST-SSR and genomic-SSR markers to assess genetic diversity in Jatropha curcas L," BMC Research Notes, vol. 3, pp. 42-49, 2010.

[30] A. P. Chan, J. Crabtree, Q. Zhao et al., "Draft genome sequence of the oilseed species Ricinus communis," Nature Biotechnology, vol. 28, no. 9, pp. 951-956, 2010.

[31] J. Yu, S. Hu, J. Wang et al., "A draft sequence of the rice genome (Oryza sativa L. ssp. indica)," Science, vol. 296, no. 5565, pp. 79-92, 2002.

[32] S. A. Goff, D. Ricke, T.-H. Lan et al., "A draft sequence of the rice genome (Oryza sativa L. ssp. japonica)," Science, vol. 296, no. 5565 , pp. 92-100, 2002.

[33] M. G. Murray and W. F. Thompson, "Rapid isolation of high molecular weight plant DNA," Nucleic Acids Research, vol. 8, no. 19, pp. 4321-4325, 1980.

[34] K. Liu and S. V. Muse, "PowerMaker: an integrated analysis environment for genetic maker analysis," Bioinformatics, vol. 21, no. 9, pp. 2128-2129, 2005.

[35] R. Peakall and P. E. Smouse, "GENALEX 6: genetic analysis in Excel. Population genetic software for teaching and research," Molecular Ecology Notes, vol. 6, no. 1, pp. 288-295, 2006.

[36] B. S. Weir, Genetic Data Analysis Methods for Discrete Genetic Data, vol. 377, Sinauer Associates, Sunderland, Mass, USA, 1990.

[37] P. Jaccard, "Nouvelles recherches sur la distribution florale," Société Vaudoise des Sciences Naturelles, vol. 44, pp. 223-270, 1908.
[38] F. J. Rohlf, NTSYS-pc: Numerical Taxonomy and Multivariate Analysis System, Version 2.2, Exeter Software, New York, NY, USA, 2005.

[39] P. H. A. Sneath and R. R. Sokal, Numerical Taxonomy: The Principles and Practice of Numerical Classification, vol. 573, Freeman Press, San Francisco, Calif, USA, 1973.

[40] S. Fujimori, T. Washio, K. Higo et al., "A novel feature of microsatellites in plants: a distribution gradient along the direction of transcription," FEBS Letters, vol. 554, no. 1-2, pp. 17-22, 2003.

[41] M. J. Lawson and L. Zhang, "Distinct patterns of SSR distribution in the Arabidopsis thaliana and rice genomes," Genome Biology, vol. 7, no. 2, pp. R14-R14.11, 2006.

[42] Y. C. Li, A. B. Korol, T. Fahima, A. Beiles, and E. Nevo, "Microsatellites: genomic distribution, putative functions and mutational mechanisms: a review," Molecular Ecology, vol. 11, no. 12, pp. 2453-2465, 2002.

[43] J. C. Mortimer, J. Batley, C. G. Love, E. Logan, and D. Edwards, "Simple sequence repeat (SSR) and GC distribution in the Arabidopsis thaliana genome," Journal of Plant Biotechnology, vol. 7, pp. 17-25, 2005.

[44] L. Zhang, D. Yuan, S. Yu et al., "Preference of simple sequence repeats in coding and non-coding regions of Arabidopsis thaliana," Bioinformatics, vol. 20, no. 7, pp. 1081-1086, 2004.

[45] C. P. Hong, Z. Y. Piao, T. W. Kang et al., "Genomic distribution of simple sequence repeats in Brassica rapa," Molecules and Cells, vol. 23, no. 3, pp. 349-356, 2007.

[46] M. V. Katti, P. K. Ranjekar, and V. S. Gupta, "Differential distribution of simple sequence repeats in eukaryotic genome sequences," Molecular Biology and Evolution, vol. 18, no. 7, pp. 1161-1167, 2001.

[47] G. Tóth, Z. Gáspári, and J. Jurka, "Microsatellites in different eukaryotic genomes: surveys and analysis," Genome Research, vol. 10, no. 7, pp. 967-981, 2000.

[48] C. P. Hong, P. Plaha, D. H. Koo et al., "A survey of the Brassica rapa genome by BAC-end sequence analysis and comparison with Arabidopsis thaliana," Molecules and Cells, vol. 22, no. 3, pp. 300-307, 2006.

[49] B. Sosinski, M. Gannavarapu, L. D. Hager et al., "Characterization of microsatellite markers in peach [Prunus persica (L.) Batsch]," Theoretical and Applied Genetics, vol. 101, no. 3, pp. 421-428, 2000.

[50] M. Morgante and A. M. Olivieri, "PCR-amplified microsatellites as markers in plant genetics," Plant Journal, vol. 3, no. 1, pp. 175-182, 1993.

[51] L. Cardle, L. Ramsay, D. Milbourne, M. Macaulay, D. Marshall, and R. Waugh, "Computational and experimental characterization of physically clustered simple sequence repeats in plants," Genetics, vol. 156, no. 2, pp. 847-854, 2000.

[52] R. Gur-Arie, C. J. Cohen, Y. Eitan, L. Shelef, E. M. Hallerman, and Y. Kashi, "Simple sequence repeats in Escherichia coli: abundance, distribution, composition, and polymorphism," Genome Research, vol. 10, no. 1, pp. 62-71, 2000.

[53] M. C. Moretzsohn, L. Leoi, K. Proite et al., "A microsatellitebased, gene-rich linkage map for the AA genome of Arachis (Fabaceae)," Theoretical and Applied Genetics, vol. 111, no. 6, pp. 1060-1071, 2005.

[54] M. La Rota, R. V. Kantety, J. U. K. Yu, and M. E. Sorrells, "Nonrandom distribution and frequencies of genomic and EST-derived microsatellite markers in rice, wheat, and barley," BMC Genomics, vol. 6, pp. 23-31, 2005.

[55] A. Sharma and R. S. Chauhan, "Identification of candidate gene-based markers (SNPs and SSRs) in the zinc and iron 
transporter sequences of maize (Zea mays L.)," Current Science, vol. 95, no. 8, pp. 1051-1059, 2008.

[56] J. M. Love, A. M. Knight, M. A. McAleer, and J. A. Todd, "Towards construction of a high resolution map of the mouse genome using PCR-analysed microsatellites," Nucleic Acids Research, vol. 18, no. 14, pp. 4123-4130, 1990.

[57] M. E. Ferguson, M. D. Burow, S. R. Schulze et al., "Microsatellite identification and characterization in peanut (A. hypogaea L.)," Theoretical and Applied Genetics, vol. 108, no. 6, pp. 10641070, 2004.

[58] A. Castillo, H. Budak, R. K. Varshney, G. Dorado, A. Graner, and P. Hernandez, "Transferability and polymorphism of barley EST-SSR markers used for phylogenetic analysis in Hordeum chilense," BMC Plant Biology, vol. 8, article no. 97, 2008.

[59] S. Senthilvel, B. Jayashree, V. Mahalakshmi et al., "Development and mapping of Simple Sequence Repeat markers for pearl millet from data mining of Expressed Sequence Tags," BMC Plant Biology, vol. 8, article 119, 2008.

[60] Y. Zhang, JI. He, P. X. Zhao, J. H. Bouton, and M. J. Monteros, "Genome-wide identification of microsatellites in white clover (Trifolium repens L.) using FIASCO and phpSSRMiner," Plant Methods, vol. 4, no. 1, pp. 19-44, 2008. 

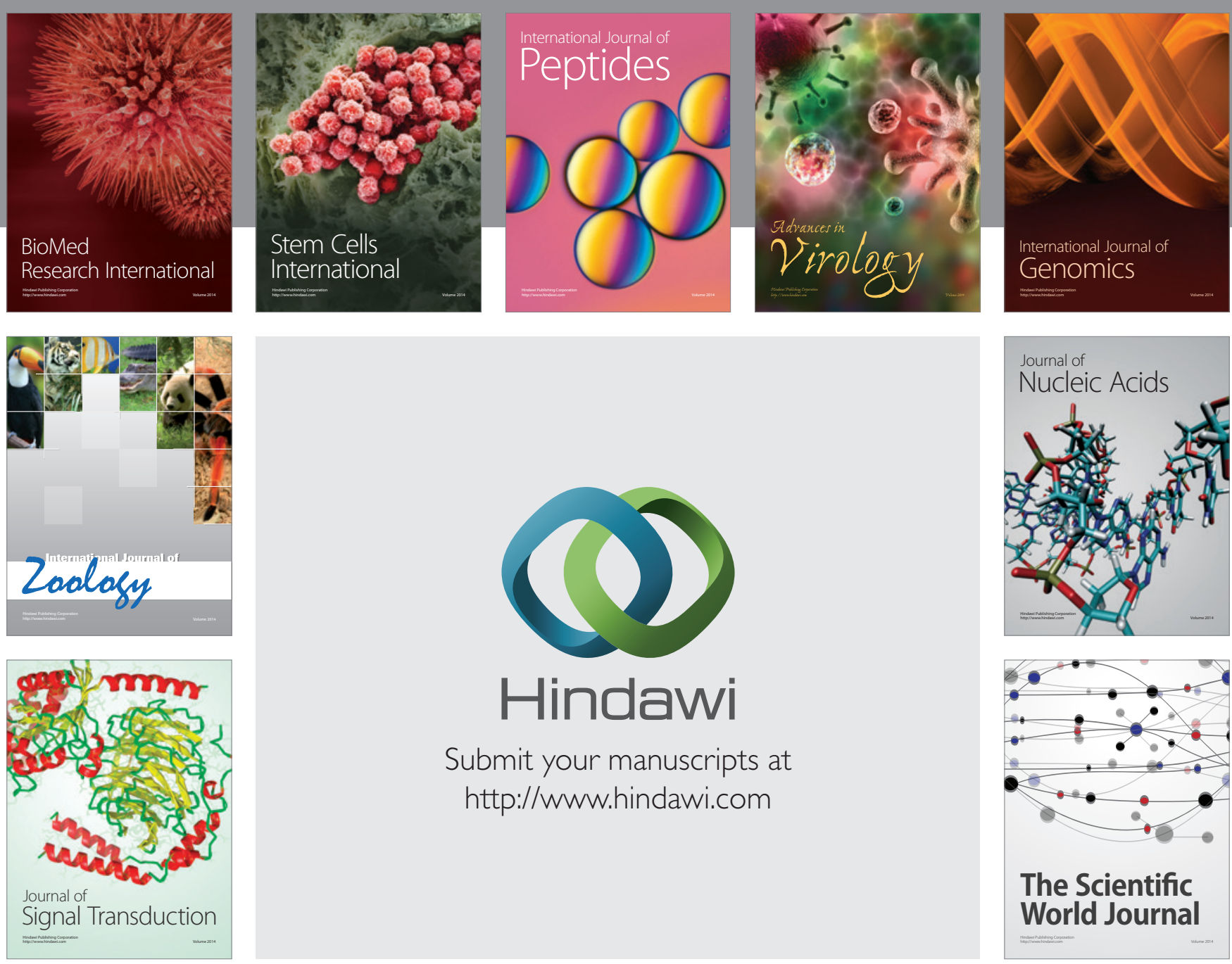

Submit your manuscripts at

http://www.hindawi.com
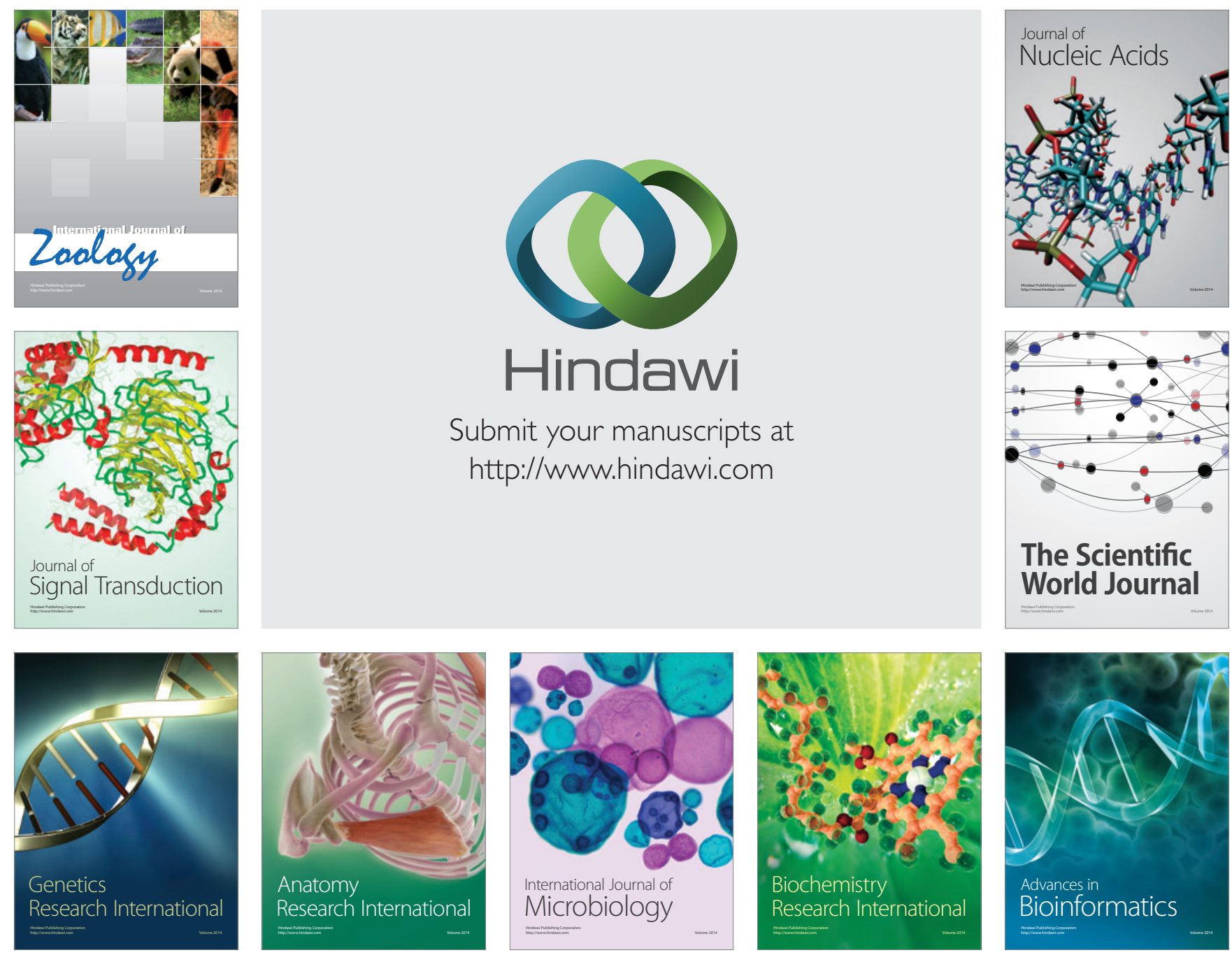

The Scientific World Journal
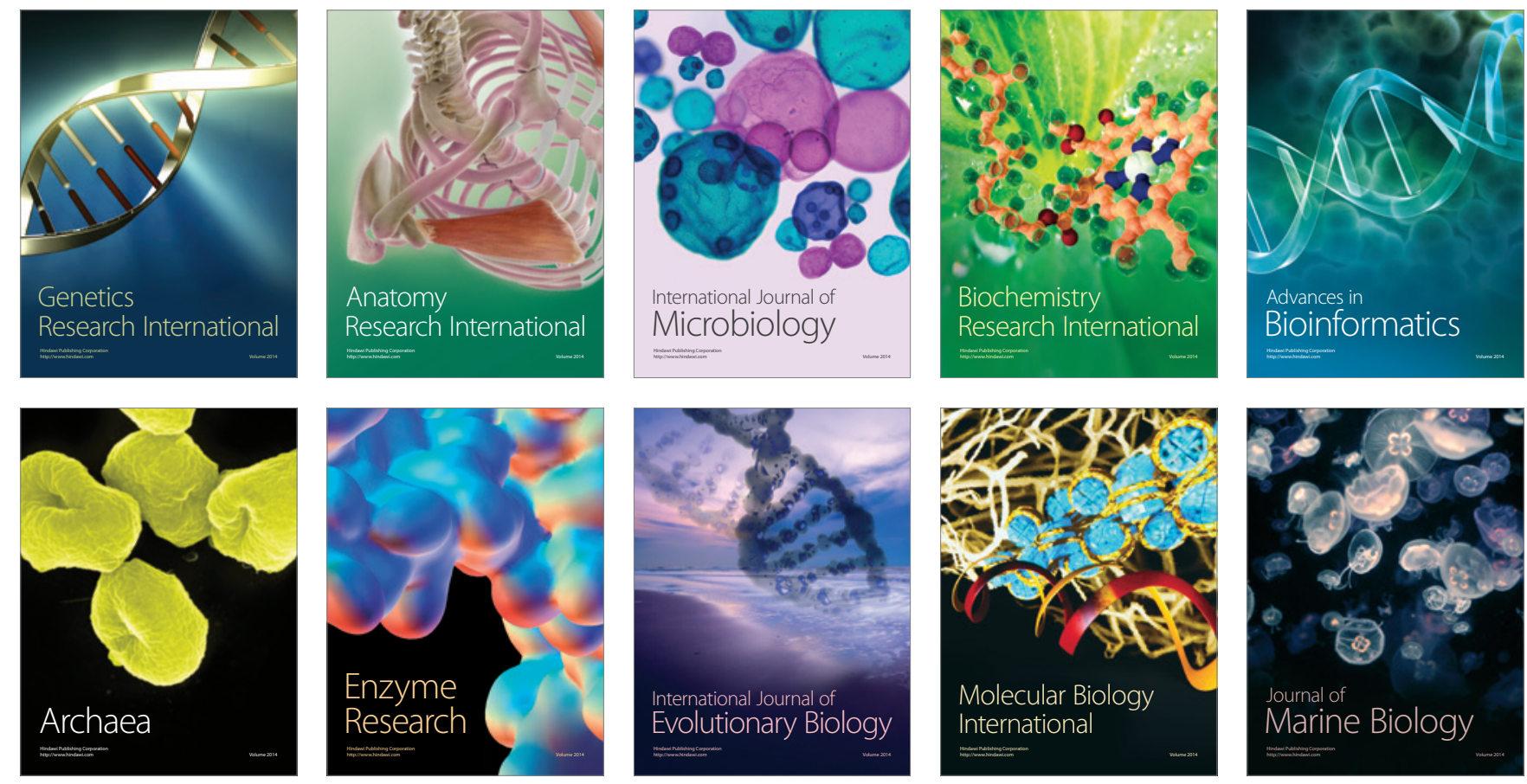